Négyesi Imre alezredes:

\title{
A MESTERSÉGES INTELLIGENCIA KATONAI FELHASZNÁLÁSÁNAK TÁRSADALMI KÉRDÉSEI
}

DOI: $\underline{\text { 10.35926/HSZ.2021.1.10 }}$

ÖSSZEFOGLALÓ: Napjainkban egyre nagyobb szerepet kap a mesterséges intelligencia; a felhasználói körből nem maradnak ki a hadseregek sem. A gépi tanuló algoritmusoknak köszönhetően a számítógépek ma már katonai feladatokat is elláthatnak. A katonai müveletek során a katonai vezetés kénytelen emberi életeket kockáztatni, sőt adott esetben feláldozni. Óhatatlanul felmerül a kérdés: Mi történik akkor, amikor ugyanezt a mesterséges intelligencia hajtja végre? A szerző már több publikációban is foglalkozott ${ }^{1,2}$ a mesterséges intelligencia katonai alkalmazásának kérdéseivel. Jelen írásában a katonai felhasználás során felmerülő etikai kérdéseket és a mesterséges intelligencia egyéb humán vonatkozásait vizsgálja nemzetközi kitekintésben.

KULCSSZAVAK: mesterséges intelligencia, etika, társadalom, morál

\section{ÁLTALÁNOS ETIKAI KÉRDÉSEK}

Stephen Hawking, a világhírü elméleti fizikus így vélekedik a kérdéskörről: „Vannak, akik szerint a számítógépek soha nem mutathatnak valódi intelligenciát, bármilyenek is legyenek. Számomra azonban úgy tünik, hogy ha az emberekben a nagyon bonyolult kémiai felépítésü molekulák képesek úgy müködni, hogy intelligensekké tesznek bennünket, akkor a hasonlóan bonyolult elektronikus áramköröket tartalmazó számítógépek ugyancsak intelligens müködést tanúsíthatnak. Ha viszont intelligensek, akkor még náluk is bonyolultabb és intelligensebb számítógépeket tudnak tervezni."3

A következő, Yuval Noah Harari izraeli történésztől, írótól átvett két idézet is bizonyítja, hogy miután a kifejezetten a hadseregek számára fejlesztett mesterségesintelligencia-alkalmazások mellett a katonai szervezetek használnak egyéb mesterségesintelligencia-alkalmazásokat is, mindenképpen vizsgálnunk kell a felhasználás etikai kérdéseit a katonai feladatok végrehajtásának vonatkozásában. A fő veszély Harari szerint: „A mesterséges intelligencia és gépi tanulás fejlődésével olyan tökéletes totalitárius rendszer építhető, amit még nem

1 Porkoláb Imre - Négyesi Imre: A mesterséges intelligencia alkalmazási lehetőségeinek kutatása a haderőben. Honvédségi Szemle, 2019/5. https://honvedelem.hu/images/media/5f2bd1646eeb8298912683.pdf (Letöltés időpontja: 2020. 08. 30.)

2 Négyesi Imre: A mesterséges intelligencia és a hadseregek. Hadtudomány, 2019/3. http://mhtt.eu/had tudomany/2019/2019_3/2019eA\%20mesterséges\%20intelligencia\%20és\%20a\%20hadseregek_Négyesi\%20Imre. pdf (Letöltés időpontja: 2020. 08. 30.)

3 https://www.citatum.hu/szerzo/Stephen_Hawking/3 (Letöltés időpontja: 2020. 06. 01.) 
láttunk korábban.”" Bár ez csak egy vélemény a sok közül, de a veszélyt valóban magában hordozza a mesterséges intelligencia. A történész-író a katonai alkalmazások tekintetében is eléggé szkeptikusan nyilatkozott: „Az önmüködő fegyverek és gyilkos robotok technológiája veszélyesebb lehet akár a nukleáris fegyverkezésnél is, mert a nukleáris fegyverkezés esetében az irányítás kizárólagosan emberi döntések és együttműködés kérdése volt. A mesterséges intelligenciával olyan technológiát fejlesztünk, amelynek az irányítása nincs teljesen az emberiség kezében: ez a technológia képes lesz helyettesíteni az emberi elmét, és átvenni az irányítást az emberiségtől az élet számos területén." ${ }^{5}$

Véleményem szerint tehát indokolt a katonai etikai kérdések felvetése. Ennek megfelelően először nézzük meg milyen általános etikai problémákat vetett fel ez idáig a mesterséges intelligencia használata. Ezek a kérdések merültek fel többek között:

- Hogyan védjük meg az emberek magánéletét?

- Ha a mesterséges intelligenciának olyan sok adatra van szüksége, akkor hogyan biztosíthatók a személyiségi jogok?

- Hogyan dönthet a mesterséges intelligencia objektíven?

- Hogyan kerüli el a mesterséges intelligencia a nemek szerinti részrehajlást az ítéleteiben?

- Hogyan veszi figyelembe a mesterséges intelligencia az emberek egymástól eltérö értékrendjét?

- Mit tekinthetünk a mesterséges intelligencia döntései közül igazságos döntésnek?

- Bízhatunk-e a médiában az algoritmikusan létrehozott és elosztott dezinformációval ellenére?

A mesterséges intelligencia fontosságát jól mutatja, hogy az Amerikai Egyesült Államokban a Fehér Ház 10 alapelvet adott ki az állami ügynökségek számára, ${ }^{6}$ amelyeket be kell tartaniuk, amikor új, a magánszektorra vonatkozó mesterségesintelligencia-rendeleteket javasolnak. Az alapelveket a Fehér Ház Tudományos és Technológiai Politikai Irodája ${ }^{7}$ adta ki három fó cél figyelembevételével, melyek az alábbiak:

- biztosítani a közvélemény részvételét;

- korlátozni a túlszabályozást;

- elösegíteni a megbízható, tisztességes, átlátható és biztonságos mesterséges intelligenciát. ${ }^{8}$

A mesterséges intelligencia és az etikai kérdések vizsgálatának fontosságát a katonai alkalmazások tekintetében alátámasztja az Amerikai Egyesült Államok Védelmi Minisztériuma ${ }^{9}$ által kiadott „Summary of the 2018 department of Defense Artifical Intelligence Strategy Harnessing AI to Advance Our Security and Prosperity"10 címü dokumentum, amelynek egy része külön foglalkozik a mesterséges intelligencia és az etika összefüggésével.

\footnotetext{
${ }^{4}$ https://www.citatum.hu/szerzo/Yuval_Noah_Harari (Letöltés időpontja: 2020. 06. 01.)

${ }^{5}$ https://www.citatum.hu/szerzo/Yuval_Noah_Harari (Letöltés időpontja: 2020. 06. 01.)

${ }^{6}$ Justin Viktor: Az USA kiadta a mesterséges intelligencia tízparancsolatát. Rakéta, 2020. 01. 29. https://raketa. hu/az-usa-kiadta-a-mesterseges-intelligencia-tizparancsolatat (Letöltés időpontja: 2020. 06. 01.)

7 Office of Science and Technology Policy - OSTP: Office of Science and Technology Policy,

${ }^{8}$ E kérdésköröket az 1. és a 2. lábjegyzetben feltüntetett publikációimban részletesen elemeztem.

9 Department of Defense - DoD.

${ }^{10}$ Summary of the 2018 Department Of Defense Artificial Intelligence Strategy. https://media.defense.gov/2019/ Feb/12/2002088963/-1/-1/1/SUMMARY-OF-DOD-AI-STRATEGY.PDF (Letöltés időpontja: 2020. 06. 01.)
} 


\section{TÁRSADALMI ÉS JOGI KÉRDÉSEK}

A fentebb megfogalmazott általános társadalmi kérdésekkel összefüggésben tekintsük át részletesebben a mesterséges intelligencia telepítésével kapcsolatos fö etikai dilemmákat és erkölcsi kérdéseket. A kérdéskör vizsgálatánál figyelembe kell venni a mesterséges intelligenciának a gazdasági növekedésre, a termelékenységre, a munkaerőpiacra, ezen belül a demográfiai folyamatokra, a digitális megosztottságra és a mesterséges intelligencia munkahelyi alkalmazásának következményeire gyakorolt hatásait is. Vizsgálni kell, hogy miként lehetne megosztani, széles körüvé tenni a társadalmon belül a mesterséges intelligencia elönyeit. Át kell tekinteni azt is, hogy a mesterséges intelligencia technológiájának nagy internetes társaságokban történő koncentrálódása milyen kérdéseket vethet fel a politikai stabilitással kapcsolatban. Nem elhanyagolható ezek mellett a mesterséges intelligencia és a demokrácia, az emberi jogok, az emberi méltóság, valamint a magánélet összefüggéseinek vizsgálata sem.

A mesterséges intelligenciát használó, „társadalmi szerepet” vállaló intelligens robotok esetében figyelemmel kell kísérni az emberi pszichére gyakorolt hatásokat. Számtalan kérdést vethet fel, hogy az ember-robot kapcsolatok hogyan és milyen mértékben befolyásolhatják az ember-ember kapcsolatokat. Vizsgálandó-vizsgálható a személyiség kérdése, és az is, hogy kell-e rendelkezniük a mesterségesintelligencia-rendszereknek erkölcsi iránymutatással.

A mesterséges intelligencia pénzügyi rendszerre gyakorolt hatásai már a kezdetektől érzékelhetők. A pénzügyi szakértők kijelentették, hogy a mesterséges intelligencia felelős a részvények magas kereskedési volumenéért. A pénzügyi kérdések mélyebb vizsgálata nélkül is nyilvánvaló, hogy - noha a piacok alkalmasak az automatizálásra - mesterséges intelligencia használata szándékos piaci manipulációhoz és összejátszáshoz vezethet; ez a kockázati tényezők között szerepel.

A mesterséges intelligencia technológiájának használata kérdéseket vet fel mind a polgári, mind a büntetőjog szempontjából is. Ezek közül kiemelendő, hogy a meglévő jogi keretek vonatkoznak-e a mesterséges intelligenciák által hozott döntésekre. Felmerül tehát a felelősség kérdése. Ugyanakkor valószínütlennek tünik, hogy a mesterséges intelligencia megfelelő autonómiával és erkölcsi érzékkel rendelkezzen, így felelőssé legyen tehető bizonyos elkövetett cselekményekért. Elképzelhető, hogy az „emberi szereplő" a mesterséges intelligencia „mögé bújva” igyekeznek elhárítani a felelősséget, azzal, hogy azt állítják: nincsenek tisztában vele, hogy a mesterséges intelligencia képes lehet-e megtenni egy adott cselekedetet.

Kérdésként merülhet fel, hogy a mesterséges intelligencia elkövethet-e büncselekményeket, például csempészést (pilóta nélküli jármüvek használatával), valamint zaklatást, kínzást, szexuális büncselekményeket, lopást, csalást, bántalmazást. Valószínüleg az önvezető autók is újabb, bonyolult jogi kérdéseket vetnek fel a felelősséggel kapcsolatban (jelenleg a biztosítók általában igyekeznek elkerülni a „ki a hibás?” kérdéssel kapcsolatos pereskedést).

A mesterséges intelligencia széles körü telepítése pozitív és negatív hatást egyaránt gyakorolhat a környezetre, ezért ezt a kérdéskört is vizsgálnunk kell. A negatív hatások között a természeti erőforrások kizsigerelését, a ritkaföldfémek nagy volumenű kitermelését (a ritkaföldfémek ugyanis alapban mérgezőek, bányászatuk és finomításuk veszélyes és durván környezetszennyező), az energiafogyasztás növekedését említhetjük, míg pozitív hatás elsősorban a hulladékgazdálkodás terén tapasztalható. 


\section{KATONAI ETIKAI KÉRDÉSEK}

A mesterséges intelligenciát használó fegyverrendszerekre különös figyelmet kell fordítanunk, ugyanis a katonai tevékenységek súlyos károkat okozhatnak a társadalom számára. A kérdés az, hogy a mesterséges intelligencia alkalmazása súlyosbítja vagy enyhíti ezeket a hatásokat. A publikált esettanulmányok feltárják a mesterséges intelligencia hadviselésben való alkalmazásának kérdéseit, valamint a mesterségesintelligencia-alkalmazások fegyverként való felhasználásának lehetőségeit. Ide tartoznak: a halálos autonóm fegyverek, a dróntechnológiák, a gyilkos robotok és mobil robot improvizált robbanóeszközök.

A mesterséges intelligencia szélesebb körü katonai felhasználása során felmerülő kulcsfontosságú etikai szempontok közé tartoznak az emberi élettel kapcsolatos kérdések, mert ezek sérthetik a nemzetközi humanitárius jogot. Ha a mesterséges intelligencia fokozott használata csökkentené a háborús küszöböt, ez jelentősen befolyásolná a globális stabilitást.

Bár a katonai technológiában a második világháború óta már alkalmaznak autonóm és intelligens rendszereket, a gépi tanulás és a mesterséges intelligencia fejlődése fordulópontot jelent az automatizálás hadiüzemekben történő alkalmazásában. A mesterséges intelligencia már elég fejlett és kifinomult ahhoz, hogy számos területen - például a müholdfelvételek elemzésénél és a kibervédelemben - alkalmazzák, ugyanakkor teljes körü felhasználását még nem sikerült megvalósítani. Egy közelmúltbeli jelentés arra a következtetésre jutott, hogy a mesterségesintelligencia-technológia képes a hadviselést ugyanolyan, vagy akár még nagyobb mértékben átalakítani, mint a nukleáris fegyverek, a repülőgépek, a számítógépek és a biotechnológia megjelenése. ${ }^{11}$

A következőkben megvizsgáljuk, hogy a mesterséges intelligencia milyen hatással lesz a haderőre. A mesterséges intelligencia széles körü bevezetésével valószínüleg folytatódni fog a folyamat, miszerint a haderők egyre inkább átadják a hatalmat a technikának, ez pedig a mesterséges intelligencia által inspirált fegyverkezési versenyhez vezethet. Az orosz katonai ipari bizottság ${ }^{12}$ tervei szerint az orosz haderő 30\%-a teljesen távvezérelt és autonóm robotplatformokból áll majd 2030-ig. Más országok valószínűleg hasonló célokat tűznek ki. Míg az Egyesült Államok Védelmi Minisztériuma korlátozásokat vezetett be a halálos erőt gyakorló autonóm és félig autonóm rendszerek használatáról, más országok és nem állami szereplők nem gyakorolhatnak ilyen önmegtartóztatást.

A döntések és tervek hátterében elsősorban pénzügyi megfontolások állnak. Egy napjainkban használatos korszerü katonai repülőgép több mint 100 millió dollárba is kerülhet, ellenben egy kiváló minőségű, kis méretü pilóta nélküli légi jármü jelenleg körülbelül 1000 dollárért megvásárolható, ami azt jelenti, hogy egy csúcskategóriás repülőgép áráért a katonaság igen nagy számban szerezhet be drónt. Noha a jelenlegi kereskedelmi drónok korlátozott hatótávolsággal rendelkeznek, a jövőben ez a ballisztikus rakétákéhoz hasonló lehet, így elavulttá válnak a meglévő platformok. Az olcsó, nagy teljesítményü halálos és autonóm robotok megjelenése komoly etikai kéréseket vethet fel. A szélesebb körben elterjedt és könnyebben hozzáférhető drónok lehetővé teszik a célzott gyilkosságot.

Mivel a kereskedelmi robotok és autonóm jármü-technológiák elterjedtek, ezért néhány csoport korszerübb, továbbfejlesztett robbanókészülékeket készít. Jelenleg a robbanóanyagok

\footnotetext{
${ }^{11}$ Gregory C. Allen - Taniel Chan: Artificial Intelligence and National Security. Harvard Kennedy School: Belfer Center for Science and International Affairs. https://www.belfercenter.org/publication/artificial-intelligenceand-national-security (Letöltés időpontja: 2020. 06. 01.)

12 Russian Military Industrial Committee (oroszul: Военно-промышленная комиссия Российской Федерации).
} 
nagy távolságra történő célba juttatásának technológiai képességével csak a nagyobb nemzetek rendelkeznek. Ha azonban a drónok általi nagy távolságú csomagszállítás valósággá válik, a millió dolláros nagyságrendü költségek ezres vagy akár százas nagyságrendre is csökkenhetnek. Hasonlóképpen, az önjáró autók gyakoribbá és pusztítóbbá tehetik az öngyilkos autóbombákat, mivel már nem igényelnek öngyilkos vezetőt.

Wael B. Hallaq ${ }^{13}$ már 2017-ben kiemelte azokat a kulcsfontosságú területeket, ahol a gépi tanulás valószínüleg befolyásolja a hadviselést. Leírt egy példát, amely szerint a parancsnok alkalmazhatna egy olyan intelligens virtuális asszisztenst harci környezetben, amely automatikusan beolvassa a műholdas képeket az egyes jármütípusok felismerése érdekében, segítve a veszélyek előzetes azonosítását. Megjósolhatná az ellenség szándékát is, és összehasonlíthatná a helyzeti adatokat a korábbi háborús harcok tárolt adataival - ezt a feladatot eddig egy tapasztalt és képzett törzs hajtotta végre, biztosítva a parancsnok számára a harc vezetéséhez szükséges információkat.

A mesterséges intelligencia hadviselésben történő alkalmazása számos jogi és etikai kérdést vet fel. Az egyik aggodalom az, hogy az emberi megítélést kizáró automatizált fegyverrendszerek megsérthetik a nemzetközi humanitárius jogot, és veszélyeztethetik az élethez való alapvető jogunkat és az emberi méltóság elvét. A nemzetközi humanitárius jog tágabb értelemben a nemzetközi jognak az a területe, amely a fegyveres konfliktusokkal és az azok során tanúsított magatartások szabályozásával foglalkozik (ius in bello). Mint fentebb már szóltunk róla, a mesterséges intelligencia csökkentheti a háborús küszöböt és hatással lehet a globális stabilitásra, ezen belül a nemzetközi humanitárius jog szabályozási céljának elérésére, ami a fegyveres konfliktusok káros hatásainak csökkentése, elsődlegesen a nem harcolók, a sebesültek, a polgári személyek, a hadifoglyok védelme, illetve az okozott károknak az éppen még szükséges szintre szorítása.

A nemzetközi humanitárius jog előírásai szerint a katonai mủveletnek (támadásnak) mint harci cselekménynek arányosnak kell lennie, nem szabad a civil lakosságra vagy polgári vagyontárgyakra irányulnia. Ezenkívül egyetlen támadás sem súlyosbíthatja feleslegesen a harcosok szenvedését. Előfordulhat, hogy a mesterséges intelligencia nem képes ezeket az elveket teljesíteni emberi döntés bevonása nélkül. Létezhet olyan autonóm katonai robottípus, amely a halálos erő (lethal/deadly force) segítségével önállóan keres és jelöl ki célokat; adott esetben ez nem felel meg a nemzetközi humanitárius jog által meghatározott normáknak, mivel nem képes megkülönböztetni a civileket a harcosoktól, ezáltal nem tudja megítélni, hogy a támadás arányos-e az okozott polgári károk tekintetében.

\section{A FELHASZNÁLÁS ALAPELVEI, SZABÁLYOZÁS}

Az Európai Bizottság mesterséges intelligenciáról szóló közleménye ${ }^{14} 2018$ áprilisában jelent meg, és előkészítette az utat a mesterséges intelligenciával kapcsolatos első nemzetközi stratégia létrehozása felé. A dokumentum összehangolt megközelítést mutat be a mesterséges intelligencia előnyeinek maximalizálása és a kihívások kezelése érdekében. A mesterséges intelligenciáról szóló közleményt kilenc hónappal később formalizálták a mesterséges intelligenciáról szóló

\footnotetext{
13 Wael B. Hallaq, a Columbia Egyetem professzora.

${ }^{14}$ European Commission (2018a). Communication from the Commission to the European Parliament, the European Council, the Council, the European Economic and Social Committee and the Committee of the Regions on Artificial Intelligence for Europe. https:/ec.europa.eu/digital-singlemarket/en/news/communication-artificialintelligence-europe (Letöltés időpontja: 2020. 06. 01.)
} 
összehangolt terv bemutatásával. ${ }^{15}$ A terv hét célkitüzést határozott meg, amelyek magukban foglalják az induló vállalkozások finanszírozását, 1,5 milliárd eurós beruházást több „kutatási kiválósági központba", a PhD-dolgozatok megírásának támogatását a mesterséges intelligencia témakörében és közös európai adatterek létrehozását is.

A következő lépésben a bizottság kinevezte az etikai iránymutatások kidolgozására szolgáló független, magas szintü szakértői csoportot, amely egy külön dokumentumban felsorolta az iránymutatásait és azokat a fö követelményeket, amelyeknek a mesterségesintelligencia-rendszereknek meg kell felelniük ahhoz, hogy megbízhatóak legyenek. ${ }^{16}$ A szabályozási folyamat részeként az Európai Bizottság további dokumentumaiban számos fontos ajánlást fogalmazott meg az emberek védelme és az elterjedés növelése érdekében, majd 2019 szeptemberében létrehozott egy mesterséges intelligencia ad hoc bizottságot (CAHAI), amely a mesterséges intelligencia fejlesztésének és alkalmazása jogi keretének, lehetséges elemeinek vizsgálatára hivatott az emberi jogok, a demokrácia és a jogállamiság elveire alapozva. ${ }^{17}$ Mindezek után az Európai Bizottság elnöke, Ursula von der Leyen bejelentette, hogy kiadták a mesterséges intelligencia „emberi és etikai következményeire” vonatkozó összehangolt megközelítésröl szóló jogszabályokat. ${ }^{18}$ Ezzel tehát az Európai Bizottság egységes keretet biztosított a mesterséges intelligencia fejlesztéséhez az Európai Unióban a tagállamoknak, de elöírta, hogy a tagállamok szintén kötelesek kidolgozni saját nemzeti stratégiájukat.

A következökben tekintsük át röviden, hol tartanak 2020-ban a tagállamok a szabályozások kidolgozásában. (A magyar nemzeti Mesterséges Intelligencia Stratégiát a Mesterséges Intelligencia Koalíció ${ }^{19}$ készíti elő. Ennek a stratégiának az elemzése egy későbbi írásom tárgya lesz.) Finnország volt az első tagállam, amely kidolgozta a mesterséges intelligenciával kapcsolatos nemzeti programot (a finn Gazdasági és Foglalkoztatási Minisztérium irányításával). ${ }^{20}$ A politikai célkitüzések az üzleti versenyképességre és a közszolgáltatásokra összpontosítanak. Dánia, Franciaország, Németország, Svédország és az Egyesült Királyság szintén bejelentette a mesterséges intelligenciával kapcsolatos nemzeti kezdeményezéseit. A dán kormány - a digitális növekedés stratégiájának megjelentetése után - 2019 márciusában közzétette a mesterséges intelligenciával kapcsolatos nemzeti stratégiát. Ez az átfogó keretrendszer felsorolja a célkitüzéseket, köztük az etikus adatkezelésre, a felelősségre, a biztonságra és az átláthatóságra vonatkozó alapelveket. Az alapelvek kiadásával párhuzamosan etikai tanácsot hoztak létre, melynek feladata az ország technológiai fejlődésének figyelemmel kísérése.

15 European Commission (2018b). Communication from the Commission to the European Parliament, the European Council, the Council, the European Economic and Social Committee and the Committee of the Regions - Coordinated Plan on Artificial Intelligence (COM(2018) 795 final). https://ec.europa.eu/digital-single-market/ en/news/coordinated-plan-artificial-intelligence (Letöltés időpontja: 2020. 06. 01.)

${ }^{16}$ European Commission (2018c). High-level expert group on artificial intelligence: Draft ethics guidelines for trustworthy AI. Brussels. https://ec.europa.eu/futurium/en/system/files/ged/ai_hleg_draft_ethics_guidelines_18_ december.pdf (Letöltés időpontja: 2020. 06. 01.)

${ }^{17}$ Council of Europe. Ad Hoc Committee on Artificial Intelligence - CAHAI. https://www.coe.int/en/web/ artificial-intelligence/cahai (Letöltés időpontja: 2019. 10. 29.)

${ }^{18}$ Laura Kayali: Next European Commission takes aim at AI. POLITICO. https://www.politico.eu/article/ai-dataregulator-rules-next-european-commission-takes-aim/ (Letöltés időpontja: 2019. 08. 27.)

19 Az innovációs és technológiai miniszter által kezdeményezett Mesterséges Intelligencia Koalíció (MI Koalíció) célja, hogy Magyarország a mesterségesintelligencia-fejlesztések és -alkalmazások terén az európai élvonalba kerüljön, és a nemzetközi MI közösség fontos tagjává váljon. Az MI Koalíció működését a Digitális Jólét Program (DJP) biztosítja.

${ }^{20}$ Finland's Age of Artificial Intelligence. https://julkaisut.valtioneuvosto.fi/bitstream/handle/10024/160391/ TEMrap_47_2017_verkkojulkaisu.pdf (Letöltés időpontja: 2020. 06. 01.) 
Franciaországban az „AI for Humanity” 2018 márciusában indult, és vállalta a francia tehetségek támogatását, az adatok jobb felhasználását és a mesterséges intelligencia etikai keretének létrehozását. Macron francia elnök elkötelezte magát amellett, hogy biztosítja az átláthatóságot és a mesterséges intelligencia tisztességes felhasználását. A stratégia elsősorban Cédric Villani, francia matematikus és politikus munkáján alapult, akinek a mesterséges intelligenciáról szóló 2018. évi jelentése a gazdaságpolitika, a kutatási infrastruktúra, a foglalkoztatás és az etika terén tett ajánlásokat.

A német mesterségesintelligencia-stratégiát 2018 novemberében fogadták el, melyben három fő vállalást tettek: Németországot globális vezetővé tenni a mesterséges intelligencia fejlesztésében és használatában, biztosítani annak felelősségteljes fejlesztését és használatát, valamint integrálni azt a társadalomba etikai, jogi, kulturális és intézményi értelemben egyaránt. Az egyéni célok között szerepel a kutatás kiválósági központjainak fejlesztése, a mesterséges intelligencia számára német megfigyelőközpont létrehozása, a mesterséges intelligencia 50 kiemelt pályázatának finanszírozása a környezet érdekében, a mesterséges intelligencia irányelveinek az adatvédelmi törvényekkel összhangban való kidolgozása.

Svédországnak a mesterséges intelligenciával kapcsolatos megközelítése kevésbé specifikus kifejezéseket tartalmaz, ám általános útmutatást nyújt az oktatás, a kutatás, az innováció és a mesterséges intelligencia infrastruktúrája számára. Az ajánlások között szerepel egy erős kutatási bázis kiépítése, az ágazatok közötti és más országokkal való együttmüködés, a kockázatok megelőzésére és kezelésére irányuló erőfeszítések fejlesztése, valamint a mesterséges intelligencia használatát irányító etikai szabványok kidolgozása. Létrehozták az ipar és a tudományos élet szakértőiből álló svéd Mesterséges Intelligencia Tanácsot is, ami kifejleszti a mesterséges intelligencia „svéd modelljét”, mely szerint a mesterséges intelligencia fenntartható, hasznos a társadalom számára és elömozdítja a hosszú távú gazdasági növekedést.

Az Egyesült Királyság kormánya 2018 áprilisában - az „,ipari stratégia” részeként - kiadta az átfogó „Mesterséges intelligencia ágazati megállapodást”, ${ }^{21}$ amelynek célja a termelékenység növelése az üzleti vállalkozásokba és az infrastruktúra-fejlesztésbe történő befektetés révén. A kormány egymilliárd fontos invesztíciót helyezett kilátásba a mesterséges intelligencia fejlesztésének előmozdítására az Egyesült Királyságban. A támogatás öt kulcsfontosságú területre irányulna: ötletek, humán erőforrás, infrastruktúra, üzleti környezet és munkahelyek. A kiemelt célok közül a legfontosabbak: a kutatási és fejlesztési beruházások arányának a GDP 2,4\%-ára valót növelése 2027-ig; több mint 400 millió font befektetés realizálása a matematika, a digitális és a müszaki oktatás területén; nemzeti átképzési rendszer kidolgozása a mesterséges intelligencia alkalmazásával kapcsolatos készségek növelése érdekében. A felsorolt befektetési kötelezettségvállalások mellett az említett ágazati megállapodás rendelkezik az ún. Adat-etikai és Innovációs Központ ${ }^{22}$ létrehozásáról a mesterséges intelligencia biztonságos és etikus használatának biztosítása érdekében. A tervek szerint a központ értékelni fogja a mesterséges intelligencia kockázatait, felülvizsgálja a szabályozási és irányítási kereteket, és a már alkalmazott új eszközök elemzései alapján tanácsot ad a kormánynak és az új technológiák fejlesztőinek.

\footnotetext{
${ }^{21}$ Artificial intelligence industry agreement, GOV.UK, 2019. The UK's Industrial Strategy. https://www.gov.uk/ government/topical-events/the-uks-industrial-strategy (Letöltés időpontja: 2020. 06. 01.)

${ }^{22}$ Centre for Data Ethics and Innovation (CDEI).
} 
Számos más európai ország is jó úton halad a nemzeti stratégiák kiadásában. Ausztria „Robottanácsot" ${ }^{23}$ hozott létre, hogy segítse a kormányt egy nemzeti mesterségesintelligenciastratégia kidolgozásában. Észtország hagyományosan gyorsan alkalmazta az új technológiákat, ideértve a mesterséges intelligenciát is. Az észt szakemberek kidolgozták a nemzeti mesterségesintelligencia-stratégiát, amely figyelembe veszi az etikai következményeket, valamint gyakorlati gazdasági ösztönzőket és kísérleti programokat kínál. Olaszország létrehozott egy munkacsoportot a mesterséges intelligencia által kínált lehetőségek felkutatására és a közszolgáltatások minőségének javítására. Fehér könyvükben ${ }^{24}$ leírták, hogy az etikai követelményeknek való megfelelés az első számú kihívás a mesterséges intelligencia sikeres megvalósítása szempontjából. Rögzítették, hogy a mesterséges intelligencia fö célja a polgárok szolgálata a technológia felhasználásával. A munkacsoport részletesen vázolja a technológia fejlesztésével, a készségek hiányával, az adatok elérhetőségével és minőségével, valamint a jogi kerettel kapcsolatos kihívásokat. Összesen 10 ajánlást tesz a kormánynak, amelyek segítséget jelenthetnek a politikai vezetésnek a megvalósítás szervezésekor. ${ }^{25}$

Érdekes lehet még Oroszország helyzete. Annak ellenére, hogy a sajtóközlemények szerint az oroszországi fejlesztések a katonai területre fókuszálnak, az országnak jelenleg nincs nemzeti stratégiája a mesterséges intelligencia vonatkozásában. A „Mesterséges intelligencia: problémák és megoldások" címü 2018. évi konferenciát követően az orosz védelmi minisztérium kiadta a szakpolitikai ajánlások listáját, amely tartalmazza a mesterséges intelligencia oktatásának állami rendszerét.

Tekintsünk Európán túlra is. Észak-Amerikában Kanada volt az első ország a világon, amely már 2017 márciusában elindította a nemzetiintelligencia-stratégia megvalósítását. A pánkanadai mesterségesintelligencia-stratégiát négy fő célkitüzés megvalósítására hozták létre: kutatók és diplomások bevonása Kanadában, tudományos kiválósági központok létrehozása Edmontonban, Montrealban és Torontóban; a globális gondolkodás fejlesztése a mesterséges intelligencia gazdasági, etikai, politikai és jogi vonatkozásaiban; a mesterséges intelligencia nemzeti kutatóközösségének támogatása.

Ázsia sok tekintetben vezető szerepet játszott a mesterséges intelligencia témakörében, hiszen - az Egyesült Arab Emírségek után - Japán volt a második ország, amely kiadta a mesterséges intelligenciával kapcsolatos nemzeti kezdeményezést. A 2017 márciusában nyilvánosságra hozott, a mesterséges intelligenciával kapcsolatos technológiai stratégia tartalmazza az iparosodási ütemtervet, érintve az egészségügy és a mobilitás területét, amelyek a népességöregedés miatt kiemelt jelentőségűek az ázsiai országban.

Japán háromlépcsős fejlesztési tervet ${ }^{26}$ állított össze a mesterséges intelligencia számára, amely egy teljesen összekapcsolt mesterségesintelligencia-ökoszisztémába vezet, és amely valamennyi társadalmi területen működik.

${ }^{23}$ Robot Council, Austrian Council on Robotics and Artificial Intelligence. Die Zukunft Österreichs mit Robotik und Künstlicher Intelligenz positiv gestalten. White Paper des Österreichischen Rats für Robotik und Künstliche Intelligenz. 2018. https://www.acrai.at/wp-content/uploads/2019/04/ACRAI_whitebook_online_2018-1.pdf, (Letöltés időpontja: 2020. 06. 01.)

${ }^{24}$ White Paper on Artificial Intelligence at the service of citizens. Eredeti nevén: Libro bianco sull'intelligenza artificiale al servizio dei cittadini.

${ }^{25}$ Artificial Intelligence, at the service of citizens, AGID The Agency for Digital Italy, 2018. 03., 22-23.

26 Japan's AI Technology Strategy - Japanese Strategic Council for AI Technology, 2017. 
Szingapúr sem maradt le Japán mögött. Ott 2017 májusában elindult egy ötéves program Mesterséges intelligencia Szingapúrban ${ }^{27}$ címmel, amelynek célja az ország képességeinek fokozása a mesterséges intelligencia területén. A program négy fő témát érint: ipar és kereskedelem, mesterségesintelligencia-keretek és -tesztek, mesterségesintelligencia-tehetségek és -szakemberek, valamint K+F. A következő évben a szingapúri kormány további kezdeményezéseket jelentett be a mesterséges intelligencia irányításával és felhasználásának etikai elveivel kapcsolatban, ideértve a mesterséges intelligencia és az adatok felhasználásával foglalkozó etikai tanácsadó testület felállítását. ${ }^{28}$

Kína óriási gazdasági növekedést mutatott az elmúlt évtizedekben, így a világ második legnagyobb gazdasága lett. Annak érdekében, hogy az ország a mesterséges intelligencia terén világelső legyen, a kínai kormány 2017 júliusában tervet adott $\mathrm{ki}^{29}$ a mesterséges intelligencia fejlesztésére. A terv részletesen meghatározza az iparosítás, a $\mathrm{K}+\mathrm{F}$, az oktatás, az etikai normák és a biztonság terén megvalósítandó célokat. Japánhoz hasonlóan háromlépcsős stratégiában gondolkodnak, amely reményeik szerint 2030-ra teljesedik ki, amikorra Kína a világ vezető mesterségesintelligencia-központjává válik.

Indiában a mesterségesintelligencia-stratégia ${ }^{30}$ úgy számol, hogy 2035-ig a mesterséges intelligencia alkalmazása 20 milliárd dollárt adhat a gazdasághoz. A cél, hogy a gazdasági növekedés mellett a társadalmi fejlödést és az,,inkluzív növekedést” is szolgálja, és kiemelt kedvezményezettjei a polgárok legyenek azáltal, hogy jobb minőségü munkát találjnak. A kormány számára összeállított jelentések ajánlásait (30 ajánlás) beépítették a megalkotott stratégiába, amelyek magukban foglalják a mesterségesintelligencia-kutatás kiválósági központjainak létrehozását, a munkavállalók átképzésének ösztönzését, a kormányzati adatbázisok megnyitását és a „technológiai fenntarthatósági tanulmányi központok” létrehozását.

Tajvan 2018 januárjában adott ki a mesterséges intelligenciára vonatkozó, az ipari innovációra fókuszáló cselekvési tervet. ${ }^{31}$ Dél-Korea 2018 májusában jelentette be „,mesterséges intelligencia információs ipari fejlesztési stratégiáját".32 A malajziai kormány 2017-ben alkotta meg a nemzeti mesterséges intelligencia keretrendszert és a digitalizáláshoz kapcsolódó feladatok listáját, ${ }^{33}$ amelyet a Malaysia Digital Economy Corporation (MDEC) vezetésével valósíthatnak meg.

27 AI Singapore. https://www.aisingapore.org (Letöltés időpontja: 2020. 06. 01.)

28 Personal Data Protection Commission Singapore. A Proposed Model Artificial Intelligence Governance Framework. 2019. https://www.pdpc.gov.sg/-/media/Files/PDPC/PDF-Files/Resource-for-Organisation/AI/A-Proposed-ModelAI-Governance-Framework-January-2019.pdf (Letöltés időpontja: 2020. 06. 01.)

${ }^{29}$ Leonid Bershidsky: Elon Musk warns battle for AI supremacy will spark Third World War. The Independent. https://www.independent.co.uk/life-style/gadgets-and-tech/news/elon-musk-ai-artificial-intelligence-worldwar-three-russia-china-robots-cyber-warfare-replicants-a7931981.html (Letöltés időpontja: 2020. 06. 01.)

${ }^{30}$ Vidushi Marda: Artificial intelligence policy in India: a framework for engaging the limits of data-driven decision-making. Philosophical Transactions of the Royal Society A: Mathematical, Physical and Engineering Sciences. 376 (2133). https://royalsocietypublishing.org/doi/abs/10.1098/rsta.2018.0087 (Letöltés időpontja: 2020. 06. 01.)

31 AI Taiwan. https://ai.taiwan.gov.tw (Letöltés időpontja: 2020. 06. 01.)

${ }^{32}$ Harshajit Sarmah: Looking East: How South Korea Is Making A Strategic Move In AI. Analytics India Magazine. https://www.analyticsindiamag.com/looking-east-how-south-korea-is-making-a-strategic-move-for-ai-leadership/ (Letöltés időpontja: 2020. 06. 01.)

33 Azura Abas: Najib unveils Malaysia's digital 'to-do list' to propel digital initiatives implementation. https:// www.nst.com.my/news/nation/2017/10/292784/najib-unveils-malaysias-digital-do-list-propel-digital-initiatives (Letöltés időpontja: 2020. 06. 01.) 
A Közel-Keleten az Egyesült Arab Emírségek volt az első ország, amely mesterségesintelligencia-stratégiát adott ki. ${ }^{34}$ A 2007-ben nyilvánosságra hozott dokumentum szerint a stratégia a kormány teljesítményének és pénzügyi ellenálló képességének fokozását szolgálja. A kilátásba helyezett beruházások az oktatásra, a közlekedésre, az energiaszektorra, a technológiai fejlödésre és az ürre összpontosítanak. A mesterséges intelligenciával kapcsolatos etikai irányelvek az igazságosságra, elszámoltathatóságra, átláthatóságra irányulnak.

Technológiai téren a világ vezető országaként számontartott Izrael még nem hirdette ki nemzeti mesterségesintelligencia-stratégiáját. Elismerik a mesterségesintelligencia-alkalmazás vezető pozíciójáért folytatott globális verseny realitását, ezért az ország Innovációs Hatósága nemrégiben készített jelentése azt javasolta, hogy Izrael dolgozzon ki nemzeti kormányzati stratégiát, amelyet „a kormány, a tudományos élet és az ipar tesz széles körben ismertté”. 35

Ausztrália 2020 elején még nem rendelkezett nemzeti stratégiával a mesterséges intelligenciáról. Ennek ellenére van „digitális gazdaságstratégiája”, amely a mesterséges intelligenciát, mint kulcsfontosságú feltörekvő technológiát jelöli meg. Az „Ausztrália technikai jövője" címü jelentés ${ }^{36}$ részletesebben foglalkozik a mesterséges intelligenciával, beleértve a közszolgáltatások és a közigazgatás hatékonyságának növelése érdekében alkalmazandó új technológiákat. Emellett felvázolja azt az etikai keretet, amely a szükséges jogalkotási reformok mellett meghatározhatja az iparral és a tudományos élettel történő együttmüködés kereteit. Az etikai keretrendszer tervezete a világ minden tájáról származó esettanulmányokon alapul, és nyolc alapelvet kínál a negatív hatások megakadályozására, köztük a méltányosságot, az elszámoltathatóságot és a magánélet védelmét. Ez az eddig legátfogóbb etikai keretek egyike a közzétettek közül, bár még ez is csak tervszinten létezik.

Új-Zélandon is folyamatban van a mesterségesintelligencia-stratégia megvalósítása; reményeik szerint bevezetése nagymértékben hozzájárul az ország GDP-jének növeléséhez. Új-Zéland Mesterséges Intelligencia Fórumát ${ }^{37}$ azért hozták létre, hogy fokozza a mesterségesintelligencia-tudatosságot és -képességet az országban, megvalósítva az ipar, a tudományos körök, a kormány és a közvélemény együttműködését. „Mesterséges intelligencia: Új-Zéland jövőjének alakítása" címü jelentésük ${ }^{38}$ számos ajánlást fogalmaz meg a kormány számára a stratégia kidolgozásának összehangolására (azaz a kutatási beruházások és a mesterséges intelligencia kormányzati szolgáltatásokban való felhasználásának koordinálására). Amenynyiben ez megvalósul, az:

- fokozza a mesterségesintelligencia-tudatosságot (ideértve a mesterséges intelligencia gazdaságra és társadalomra gyakorolt hatásainak kutatását),

- elösegíti a mesterséges intelligencia elfogadását

- javítja a megbízható adatok elérhetőségét,

- hozzájárul a mesterséges intelligencia gyártói és alkalmazói körének bővüléséhez,

- lehetővé válik a mesterséges intelligencia törvényi hátterének, etikai alapelveinek és a társadalomra gyakorolt hatásainak vizsgálata, elemzése.

${ }^{34}$ AI System Ethics Self-Assessment. https://www.smartdubai.ae/self-assessment (Letöltés időpontja: 2020. 06. 01.)

${ }^{35}$ Az Innovációs Hatóság neve, a jelentés címe, forrása.

36 The Digital Economy: Opening Up The Conversation. Department of Industry, Innovation and Science. https:// www.archive.industry.gov.au/innovation/Digital-Economy/Documents/Digital-Economy-Strategy-ConsultationPaper.pdf (Letöltés időpontja: 2020. 06. 01.)

37 AI Forum New Zealand.

${ }^{38}$ Artificial Intelligence: Shaping a Future New Zealand. https://aiforum.org.nz/wp-content/uploads/2018/07/ AI-Report-2018_web-version.pdf (Letöltés idöpontja: 2020. 06. 01.) 


\section{ÖSSZEFOGLALÁS, KÖVETKEZTETÉSEK}

A fentiekből kitetszik, hogy a világ és benne Európa egésze napjainkban egy, számos előnnyel járó, de megannyi veszélyt is hordozó technológia megjelenésével szembesül. Az idézett dokumentumok és ajánlások mindegyike arra törekszik, hogy az etikai és társadalmi szempontból előnyösebb normák irányába mozdítsa el a mesterségesintelligencia-technológiák tervezését, fejlesztését és alkalmazását. Reményeink szerint az érintett szereplők együttmüködésének nyomán - a mesterséges intelligencia társadalmi alapvető lehetőségeinek és kockázatainak, valamint az elfogadott etikai alapelvnek a felismerése alapján - konkrét és konstruktív válaszok születnek a mesterséges intelligencia által felvetett legsürgetőbb társadalmi kihívásokra, melyeket figyelembe kell venni a katonai célú mesterséges intelligenciák létrehozása során is.

\section{FELHASZNÁLT IRODALOM}

Abas, Azura: Najib unveils Malaysia's digital 'to-do list' to propel digital initiatives implementation. https://www.nst.com.my/news/nation/2017/10/292784/najib-unveils-malaysias-digital-do-listpropel-digital-initiatives

AI Singapore. https://www.aisingapore.org

AI System Ethics Self-Assessment. https://www.smartdubai.ae/self-assessment

AI Taiwan. https://ai.taiwan.gov.tw

Allen, Gregory C. - Chan, Taniel: Artificial Intelligence and National Security. Harvard Kennedy School: Belfer Center for Science and International Affairs. https://www.belfercenter.org/publication/artificialintelligence-and-national-security

Artificial Intelligence, at the service of citizens, AGID The Agency for Digital Italy, 2018. 03.

Artificial intelligence industry agreement, GOV.UK, 2019. The UK's Industrial Strategy. https://www. gov.uk/government/topical-events/the-uks-industrial-strategy

Artificial Intelligence: Shaping a Future New Zealand. https://aiforum.org.nz/wp-content/uploads/2018/ 07/AI-Report-2018_web-version.pdf

Bershidsky, Leonid: Elon Musk warns battle for AI supremacy will spark Third World War. The Independent. https://www.independent.co.uk/life-style/gadgets-and-tech/news/elon-musk-ai-artificialintelligence-world-war-three-russia-china-robots-cyber-warfare-replicants-a7931981.html

Council of Europe. Ad Hoc Committee on Artificial Intelligence - CAHAI. https://www.coe.int/en/ web/artificial-intelligence/cahai

European Commission (2018a). Communication from the Commission to the European Parliament, the European Council, the Council, the European Economic and Social Committee and the Committee of the Regions on Artificial Intelligence for Europe. https:/ec.europa.eu/digital-singlemarket/en/news/ communication-artificial-intelligence-europe

European Commission (2018b). Communication from the Commission to the European Parliament, the European Council, the Council, the European Economic and Social Committee and the Committee of the Regions - Coordinated Plan on Artificial Intelligence (COM(2018) 795 final). https://ec.europa. eu/digital-single-market/en/news/coordinated-plan-artificial-intelligence

European Commission (2018c). High-level expert group on artificial intelligence: Draft ethics guidelines for trustworthy AI. Brussels. https://ec.europa.eu/futurium/en/system/files/ged/ai_hleg_draft_ ethics_guidelines_18_december.pdf

Finland's Age of Artificial Intelligence. https://julkaisut.valtioneuvosto.fi/bitstream/handle/10024/160391/ TEMrap_47_2017_verkkojulkaisu.pdf 
Israel Innovation Authority 2018-19 Report. https:/innovationisrael.org.il/en/news/israel-innovationauthority-2018-19-report

Justin Viktor: Az USA kiadta a mesterséges intelligencia tizparancsolatát. Rakéta, 2020. 01. 29. https:// raketa.hu/az-usa-kiadta-a-mesterseges-intelligencia-tizparancsolatat

Kayali, Laura: Next European Commission takes aim at AI. https://www.politico.eu/article/ai-dataregulator-rules-next-european-commission-takes-aim/

Marda, Vidushi: Artificial intelligence policy in India: a framework for engaging the limits of data-driven decision-making. Philosophical Transactions of the Royal Society A: Mathematical, Physical and Engineering Sciences. 376 (2133). https://royalsocietypublishing.org/doi/abs/10.1098/rsta.2018.0087

Négyesi Imre: A mesterséges intelligencia és a hadseregek. Hadtudomány, 2019/3. http://mhtt.eu/ hadtudomany/2019/2019_3/2019eA\%20mesterséges\%20intelligencia\%20és\%20a\%20hadseregek_Négyesi\%20Imre.pdf, DOI 10.17047/HADTUD.2019.29.3.71

Personal Data Protection Commission Singapore. A Proposed Model Artificial Intelligence Governance Framework. 2019. https://www.pdpc.gov.sg/-/media/Files/PDPC/PDF-Files/Resource-for-Organisation/ AI/A-Proposed-Model-AI-Governance-Framework-January-2019.pdf

Porkoláb Imre - Négyesi Imre: A mesterséges intelligencia alkalmazási lehetöségeinek kutatása a haderőben. Honvédségi Szemle, 2019/5. https://honvedelem.hu/images/media/5f2bd1646eeb8298912683.pdf

Robot Council, Austrian Council on Robotics and Artificial Intelligence. Die Zukunft Österreichs mit Robotik und Künstlicher Intelligenz positiv gestalten. White Paper des Österreichischen Rats für Robotik und Künstliche Intelligenz. 2018. https:/www.acrai.at/wp-content/uploads/2019/04/ACRAI_whitebook_ online_2018-1.pdf

Sarmah, Harshajit: Looking East: How South Korea Is Making A Strategic Move In AI. Analytics India Magazine. https://www.analyticsindiamag.com/looking-east-how-south-korea-is-making-a-strategicmove-for-ai-leadership/

Summary of the 2018 Department Of Defense Artificial Intelligence Strategy. https://media.defense.gov/ 2019/Feb/12/2002088963/-1/-1/1/SUMMARY-OF-DOD-AI-STRATEGY.PDF

The Digital Economy: Opening Up The Conversation. Department of Industry, Innovation and Science. https://www.archive.industry.gov.au/innovation/Digital-Economy/Documents/Digital-EconomyStrategy-Consultation-Paper.pdf 